\title{
Labors In The Media: Detik Finance Report On Batam 2015 Labor Strikes
}

\author{
Astari Fitria Putri ${ }^{1}$, Nunik Maharani Hartoyo, Sahat Sahala Tua Saragih \\ School of Journalism Studies, Faculty of Communication Sciences, Universitas \\ Padjadjaran
}

\begin{abstract}
The impressive economic growth along with its strategic location have made the city of Batam as one of the best economic performer in Indonesia. For years, Batam has attracted foreign investors from countries such as Singapore, China, Korea, Taiwan and Malaysia. However, there was a significant decline in the period of 2013-2015. DetikFinance, an online media, reported and highlighted the fact that frequent labors demonstration and strikes were the main reasons as to why many multinational companies left Batam as well as the FDI decline. Utilizing Norman Fairclough's model for Critical Discourse Analysis (CDA), this paper finds that DetikFinance's reports are biased and the labors are painted in a non-favorable fashion: their demands are unreasonable and therefore counterproductive to the economy. In its reporting process as well as in the report texts, DetikFinance also dismisses the fact that during that period, the world economy, including Indonesia, is slowing down. Study reveals that DetikFinance media routines and ideology are in fact serving its own business interests and affect the way they construct and present their reports. In doing so, DetikFinance has violated the very principles of journalism by reporting imbalanced, unverified news and prevent them from serving the public, including business community, a comprehensive explanation of the matter.
\end{abstract}

Keywords: biased news, CDA, DetikFinance, economy report, Indonesia, labors strikes

\section{Introduction}

Labor strike has played central role in many industrial and political struggles since the industrial revolution. Strikes are used as bargaining tools to even out the leverage of parties involved, as well as to reconstruct the economic and political power and

\footnotetext{
${ }^{1}$ Korespondensi penulis :

Astari Fitria Putri, Program Studi Jurnalistik Fakultas IImu Komunikasi Universitas Padjadjaran, Jalan Raya Bandung Sumedang, KM. 21, Jatinangor, Sumedang. 45363.

astarifp@yahoo.co.id
} 
stability. Further, history also recorded that waves of strike --along with other form of protests-- frequently brought down governments and gave rise to a change of regimes (Robertson, 2007). Leading up to the downfall of the New Order Regime in 1998, numbers of labor protests in Indonesia had gone up due to the continuing inflation, failure of the job market to keep pace with the increase of labor force (Silvey, 2003). In the course of time, Indonesian labor force is getting more articulate in voicing their rights and concerns. Labors demonstration and protests are becoming more frequent, larger in size, and take strategic place for public display of force. According to Simon and Xenos (2000), to the optimistic, the media is the ideal locus for genuine public deliberation. Labor strikes, therefore, provide a theme for competing ideas as well as the interactions between elites (i.e. labor union leaders, company management and the government) in the process of public deliberation facilitated by the media. Interestingly, Joel Peress research (2014) suggests that the media are increasingly recognized as key players in financial market due to their role in disseminating information useful to the investors. His research examines national newspaper strikes in several countries and finds that trading volume and price formation are notably affected during the strikes. Thus, he concludes that the media's role in diffusing information among investors has contributed significantly to the performance of the stock market and business in general.

In Indonesia, the impressive economic growth along with its strategic location has made Batam as one of the best economic performer nationally. For years, Batam has attracted foreign investors from countries such as Singapore, China, Korea, Taiwan and Malaysia because of its relatively cheap land price and competitive labors force. Therefore, Batam is not only a significant economy driver in Indonesia, but also plays an important role for foreign export commodities and its companies. In recent years, Batam shows that it has the capability to compete with other similar Special Economic Zones in Asia Pacific region. It provides almost 350.000 jobs in 2014 alone. Therefore, the Batam authority work hard to keep it attractive to the investors and issued regulations that is favorable to foster business climate (e.g. one desk permit processing service, less than 20 days business permit processing, etc.). According to Damuri et.al. (2015) the data shows that until June 2014, $60 \%$ of the total FDI in Batam was from Singaporean investors, $11 \%$ are Malaysians, while Taiwan, Korea and China each contribute 3\% to the total FDI. The total FDI in Batam has significant growth from 2010-2012, however, there was a significant decline in the period of 2013-2015, with 125 companies had to withdrew their investment and closed down their operation in Batam. Mr. Udin P. Sihaloho, a member of Batam local legislative body, in an interview with the media, pointed out several factor contributing to the decline: 1) unfavorable regulations; 2) frequent labors strikes and demonstration; 3) inconsistencies in the law enforcement (particularly labors); and 4) corruption (Stefanus, 2015). With regard to Mr. Sihaloho statement, another report published by the city of Batam official website (2015) identified another factor: the significant increase in minimum labors wage in Batam 
City area. Many investors and business owners complained to the government and argue that such increase has made serious impact to the company's cash flow which resulted in the increase of production cost. Interestingly, the report also states that, with the competitive business competition with China and Korea, has forced many investors to relocate their businesses to Vietnam, which offers cheaper work force by $20 \%$.

The significance of the issue, and the indisputable data, facts, figures and statements, has attracted the media attentions. Moreover, the fact that there are many companies which closed their operations in Batam were and some still have unresolved issues with their employees, made it clear to the media that something needs to be done and the Indonesian public need to turn their attention to the matter. Several online media such as Tempo.co.id, Liputan6.com, Antaranews.com, Okezone.com and Suara.com discussed the issue in several publications from various angle. Tempo.co.id published 2 reports that emphasizes the difficulty to navigate through regulations and bureaucracy as the main reason as to why the investors left Batam. Suara.com chose to publish 2 stories from the companies' internal problems. Four reports published by Okezone.com took the approach to highlight issues such as labors demonstration and business competition. DetikFinance, on the other hand, since 8 July 2015, published an intensely 25 reports on the topic. It was started when the Chairman of the Investment Coordinating Board of the Republic of Indonesia (BKPM), Mr. Fransiscus MA. Sibarani or known as Mr. Franky Sibarani, stated that several multinational companies in Batam were closing down their operation due to the increasing pressure from labors demonstration. DetikFinance then following up the statement with reports highlighted the fact that frequent labors demonstration and strikes are the main reasons as to why many multinational companies left Batam as well as the FDI decline. In those 25 reports, labors representatives were only given 3 opportunities to explain their side of the story, compared to the 22 publications that are against them. Surely, the labors perspectives were not treated in equal proportion. The tone of the reports is favorable to the Government (BKPM) and significant portion of the reports were very positive to the business interests through statements from Indonesian Business Association (Apindo). Further, DetikFinance formulation of report title as well as its content structure and diction were positive to the business interests and tend to be discriminating against the labors.

One of the most important principles in Journalism is to present a balanced report to the audience and it includes the cover-both-sides principle. Moreover, Journalist should verify each data, facts and figures before making any publication. Those principles are considered as the ultimate guidelines that makes Journalism and its media as a "trust" business. In terms of balanced report in the online media, Margianto and Syaefullah (2004) explain that the attempt to present a balanced report is manifested in the updates through subsequent report(s). Each angle, each party is published in independent report, in subsequent manner. The problem is, each report can be perceived as favorable to certain party and it can be harmful to other party 
because the public opinion already formed. By the time the other party has the chance to voice their side of the story, it can be too late to sway the public opinion on the matter. Thus, online media are often accused (and often guilty as charged) to publish imbalanced news.

In their journalism activities, the Journalists and the media are often biased. The reason is because the media is right in the heart of the social reality in which full of interests, conflicts and multi-layered of facts. Media are often to be believed to have exceptional power to manipulate reality and the public awareness, it can marginalized the minority and at the same time can bring the periphery to the center. Media is also believed to be controlled by the dominating power that often resulted in distorted or even false news. In terms of labor strikes, previous findings show that media has been long understood as biased in reporting the matter and tends to exaggerate (Puette, 1992). A study done by Diane E Schmidt (1993) suggests that public opinion regarding the labor, the union and strikes is actually influenced by numerous reasons, yet she posits that media coverage on the issue is identified as one. Schmidt further explains that the tone of media coverage on the topic provides a cognitive foundation for the public to perceive the labor and its movements. Moreover, the strike-centered news has its strongest negative influence on individuals who lack ideological and group attachments to the labors. Those previous findings are actually in line with the fact that every individual is actually influenced by social structure and power, and it works through language. Language is a medium to create subject, themes and even strategies (see Hall, 1997; Ricoeur, 2012; Eriyanto, 2001). And it also applies to Journalists, the media and the public.

The objective of this paper is to discuss the labors representation in the media which focuses on DetikFinance report on Batam 2015 Labors Strikes. It seeks to explain the dynamic and complex relationship between the power and the ideology of the media that has influenced DetikFinance and its journalism activities as well as its reports.

\section{Methodology}

This is a critical study that is designed to seek a deeper understanding in order to explain the structure, systems and pattern available, that is ingrained in the phenomenon. Norman Fairclough model of Critical Discourse Analysis (CDA) is used to investigate the relationship between texts, discourse practice and its sociocultural contexts. CDA seeks to analyze the dialectical relationships between discourse (including language both verbal and nonverbal) and other elements of social practices. Fairclough (as cited in Sheyholislami) defines CDA as "a discourse analysis which aims to systematically explore often opaque relationships of causality and determination between (a) discursive practices, events and texts, and (b) wider social and cultural structures, relations and processes; to investigate how such practices, events and texts arise out of and are ideologically shaped by relations of power and struggles over power; and to explore how the opacity of these 
relationships between discourse and society is itself a factor securing power and hegemony." Further, Fairclough's model for CDA (1989) consists of three interrelated processes of analysis tied to three inter-related dimensions of discourse. These three dimensions are: 1) the object of analysis (including verbal, visual or verbal and visual texts); 2) The processes by means of which the object is produced and received (writing/ speaking/designing and reading/listening/viewing) by human subjects; and 3) the socio-historical conditions which govern these processes. Each of these dimensions requires a different kind of analysis i.e. text analysis (description), processing analysis (interpretation), and social analysis (explanation) (Fairclough, 1995). The text in this context is DetikFinance 25 reports, and its social context is the social structure, systems, believes in Batam, Indonesia and the world. Primary data is gathered through text and document analysis, as well as structured interview and observation, while secondary data is collected from literary review and document study.

\section{Finding and Discussion}

Throughout the 25 reports, DetikFinance chose its sources mainly from the Chairperson of BKPM, the Chairperson of Apindo Indonesia and Chairperson of Apindo Riau, and also published statements from other sources. Most statements were revolved around the idea that labors protests and strikes are the main reason as to why many foreign investors closed down their operation in Batam. In addition, DetikFinance also published statements speculating that many labors protests and strikes were actually part of business competition strategies done by foreign interests in an attempt to relocate FDI from Indonesia.

Interestingly, an editor of DetikFinance explains in an interview, that one of the main reasons as to why DetikFinance put blame to the labors protests and strikes is to let the labors force understand that their demands were unreasonable. To explain the labors' way to assert their concerns and demands, DetikFinance used the word "anarchistic" to tell their audience about the labors' blockade actions and forced factory locked downs. The editor explains that Batam is not Singapore, therefore, the demand to raise the city's minimum labors wage was counterproductive to the economy. DetikFinance supported such position by interviewing sources that shared the same sentiment. Considering the fact that many other media also reported the slowing down of global economy, the decline of demand, the internal problems such as acquisitions and change of management as well as the transparency and communication problems as contributing factors, DetikFinance seemed to neglect those facts and chose not to factor them in. DetikFinance stated in its report that labors protests was not acceptable and that the labors should open their communication channels with the management first. Such statement was actually inaccurate since the labors representatives already try to reach out to the management but to no avail. In this case, DetikFinance position shows that their reports were imbalanced and biased. 
One of the labors representatives from one of the company that was closed down its operation in Batam, PT. Sanmina Batam, explains in a personal correspondence, that the labors representatives already try to reach out to DetikFinance and questioned their tone of the news. The representative also asked for more balanced news and wrote a clarification at the comment section and stated that the list of the company names as reported by DetikFinance was actually inaccurate. The commentary only lasted for quite some time and later DetikFinance seemed to take it down. Following the accident, whenever the labors representative wanted to leave another comment, they did not seem to be able to post it and the reason for such curious problem was unknown. In this regard, DetikFinance has manipulated its system to prevent certain party to post their comments or make commentary to share their concern over the matter. Such practice should be interpreted as DetikFinance's attempt to create certain reality to their audience regarding labors protests and strikes.

\section{Discourse: "Watchdog" or "Lapdog"?}

The role of the reporter as an individual are actually intertwined with the news production process and the process of news consumption. It helps shape the way the news was perceived and constructed. Shoemaker and Reese (1996) argue that media worker individuals (journalists, editor, etc.) will influence the content of their reports, which in turn, will affect the content of the media. The influence came from the professional and personal background, personality, personal beliefs and attitude and other professional roles. As previously discussed, one of DetikFinance editors perceived the labors demands that were voiced in the protests and strikes as unreasonable and counterproductive. Such position is then manifested in the news published by DetikFinance. The selection of sources, the way DetikFinance treated the labors demands as unacceptable because from DetikFinance perspective the minimum wage in Batam was already high without giving comprehensive argument to support it, reinforces the negative image on the labors.

The reports, according to DetikFinance editor, were intentionally published at HOT NEWS channel/section. The objective is to allow DetikFinance to publish follow-up reports from as many angles as possible. It wanted to use the opportunity to contribute positively to the economy and prevent more foreign investors leaving the country. In this regard, the editor and DetikFinance positioned themselves from the business owner perspective and judged negatively to labors protests and strikes. The reports also use the word "keanehan" (irregularities) to the protests and strikes and use statements from authorities including statements from the President of Indonesia, the Minister of Industry and the Chaiperson of BKPM but failed to provide further elaboration.

DetikFinance's also repeatedly publish the President's statement related to the suspicion that there were foreign interests and agenda involved and that National Intelligence Agency (BIN) should investigate the irregularities of the labors protests 
and strikes in Batam. Such strategy indicates that DetikFinance considered the labors protests and strikes in Batam at the utmost importance to the national interests. DetikFinance seemed to neglect the fact that majority of labors protests and strikes were largely caused by the lack of Labors Law enforcement, sudden work termination, the increasing trend of out-sourcing, companies' prohibition to form labors union, as well as the fact that many companies shut down their operation without severance pay. National interest, in DetikFinance reports, can be interpreted as business interests, and not the labor interests.

In terms of media routines that includes daily communcation practices, deadlines and news writing principles, Shoemaker and Reese (1996) argue, are also contributing to the end result of the news report published by the media. Detik.com, the umbrella of DetikFinance, with its online platform, positioned itself as the fastest media that published the most recent news and events. Unfortunately, such position comes with a very expensive price: the sacrifice of verification and the presentation of imbalanced news.

Further, Shoemaker and Reese also points out that the external media factor are also pivotal to the report structures. The selection of sources are important and the media need to understand that news source can also be biased. Therefore, the media need to carefully select their news source carefully to avoid inaccuracy. As aforementioned, DetikFinance started their reports on the labors protests and strikes in Batam following the Chairperson of BKPM statement. However, Mr. Franky Sibarani later retracted his statement and said that investment condition in Batam is conducive and the labors protests and strikes were not to blame. Unfortunately, the retraction statement was not reported by DetikFinance. Considering many official statements form the government were given large proportions in their reports, the absence of Mr. Sibarani clarification only indicates DetikFinance firm position on the matter. It fails to fill the role of the watchdog and prevent the public to learn the truth from as many perspectives as possible.

\section{Considering Socio-Cultural: Against the Labors}

Louis Althusser (2008) argues that ideology is the representation of the imaginary individual relations to its real existence. World representation is forged and marginalized with domination as the objective. As previously discussed, DetikFinance's reports put the negative impact of labors protests and strikes to the company and the disruption to its production system, economy and the government as its central theme. It chose not to discuss the labors perspectives but pointed out the labors attitude that was perceived as negative and counterproductive. Labors protests and strikes were illustrated as anarchistic; with many blockade actions, holding hostage situations, and forced factory locked downs as the labors' way to assert their concerns and demands. Such strategy then judged as disruptive to the production and economy. On the other hand, business owners were represented as the "good guys," because of their service and positive contribution to the economy. The management 
approach to the protests and strikes were described by DetikFinance as positive and accommodating.

In its company mission, Detik.com states that it is committed to customer satisfaction, the well-being of its employee and an excellent place to build a career and create sustainable outcome to the shareholders. Detik.com positioned itself as a media with business orientation and support capitalism. Throughout the years, Detik.com has successfully created the image as the fastest online media. Yet Detik.com is also well-known for its lack of verified facts in its reports. As the front liners in Indonesia's online media business, Detik.com has the economy (through access and control) and mass media power (i.e. to inform, persuade, and influence). Both roles provide the legitimacy in creating the perception of reality and illustrate the roles of the media in becoming the watchdog of the society. It is the manifestation and tools of social power and control. With that in mind, DetikFinance also instill its ideology and opinion in their reports. The objective, is to disseminate their views that serves their own agenda. In this case, to create certain image on the labors protests and strikes subtly to its audience.

In socio-historical level, the socio-cultural practices manifested itself in the text produced by the media. Media is a potential entity that is able to reinforce certain position while marginalizing others. Hegemonic news reports, thus, occur in a very delicate process by presenting facts that considered as the truth, logic, reasonable and indisputeable. Such conditions allow Detik.com to dominate its audience with its own agenda and interests. The capitalistic approach reflected in the reports, is actually a mirror of the dominant capitalistic culture in the society. Capital is seen as the driving force of the society, and such belief is then produced and reproduced in so many level and institutions, including DetikFinance and other media outlets

It is worth noting that many Indonesians do not see themselves as part of the working class and labors movement. Thus, many tend to perceived labors movement in negative fashion. Labors movement largely did not interpreted as a movement that represents the interests of Indonesian working class. In the report titled "Diam-Diam Hengkang dari Batam" and "Contoh Vietnam, Pengusaha: Upah Buruh Naik dan Produktivitas Juga Naik", DetikFinance treated the issue with business owners perspective, i.e. labors merely are tools in production process. Further, DetikFinance also neglected the fact that Batam is part of the top five cities with the highest cost of living in Indonesia. According to Statistics Indonesia 2014, the average cost of living in Batam is IDR 6.3 millions while the city minimun wage is IDR. 2.4 millions. Such discrepancy should be factored in, in order to understand the matter comprehensively.

The way the labors protests and strikes represented by DetikFinance, is in line with Shoemaker and Reese's explaination that there is a significant influence of the media organization to the news it published. Any mass media organization has many objectives and making profit is one of the most important objectives. Further, 
Shoemaker and Reese elaborate on how organization influences the report published by the media. Editors must control reporters, publishers must control editors, and the owner(s) must control the publishers. Control is essential, given the inherent conflict within an organization. The organization must socialize individual workers to their routines and enforce them, while handling situations not covered by the routines. Most control is straightforward and accomplished through a reward system while other control is equally powerful because it is subtle and unquestioned. Other means of control include editorial blue-penciling, striking out parts of a story. Reporters soon learn what objectionable phrases or facts to leave out. In addition, executives give rare reprimands or make explicit policy, thus further enforcing the boundaries. Internal house organ papers also help tell reporters what is acceptable. In the case of DetikFinance, their organizational vision and mission and work culture dictates how the journalist and the editor work, what to cover, how to treat and report news and events and to what objectives.

As a news portal concentrating in economy sector, DetikFinance is considered attractive to many companies and industries. Their tendency to highlight the negative impact of labors protests and strikes, as well as their decision to downplay other contributing factors, can be perceived as a strategic effort to appeal the advertisers. DetikFinance 25 reports on the issue is actually a practice of commodification of content. In an interview, the editor of DetikFinance explains that advertisers cannot intervene the newsroom. However, the fact that the journalists have to produce reports that is inline with the organization objectives is significant to the end result of the report published by DetikFinance.

\section{Conclusion}

Discourse analysis shows that the text production process as well as the journalists' personal and professional background influenced the representation of the labors demonstration and strikes in Batam. The online news production process that is fast paced, has cost DetikFinance the opportunity to report a balanced, accurate and verified facts and figures for each news and events. DetikFinance also shows their tendency to voice the business owners' interests and agenda in their reports. Further, in socio-cultural level, there was a wide gap between the city of Batam living cost and minimum wage as well as many layoffs that contribute to the frequent labors demonstration and strikes. It is worth noting that during the process of text production, the world economy, including Indonesia, was slowing down. However, the reports were structured in a way that places the business owners in a dominant position and paint the labors force attitude as non-favorable. In doing so, DetikFinance has violated the very principles of journalism by reporting imbalanced, unverified news and let their own capitalistic view prevent them from serving the public a comprehensive explanation of the matter.

All things considered, the results show that DetikFinance has in fact reinforces the long standing position of the media biased in portraying labor strikes 
in their coverage. The journalists and editors need to put journalism principles and ethics first: produce accurate and balanced news by giving equal coverage and representing all sides (i.e. labor union, business owners and the government) to provide a comprehensive report to the public. Further, DetikFinance has to verify every information and statements from their sources prior publications. It should also refrained themselves from publishing any news based on presumptions, allegations or unverified statements from their source. More importantly, it also has to comply with all rules and it includes the obligation to publish a correction as soon as possible should there be any retraction of statements or inaccuracy of information in their reports. This, apparently, is the fact that DetikFinance is failing to do.

The fact that many Indonesians do not see themselves as part of the working class and labors movement only confirms Schmidt's (1993) findings, i.e. those who perceive the matter negatively are individuals lacking ideological and group attachments to the labors; and in this case, including the journalists and editors at DetikFinance. In this regard, this study recommends further investigation as to why the media (particularly in Indonesia) continues to be biased against the labors and its movement? The fact that the Indonesian media also benefited from the downfall of the New Order regime in 1998 -which also was driven by the waves and escalating labor strikes and protests-- is interesting to explore as well. Does this mean that instead of taking the role of the watchdog of those in power, the Indonesian media has surrender and become the lapdog?

\section{References}

Althusser, L. (2008). Tentang Ideologi: Strukturalisme Marxis, Psikoanalisis, Cultural Studies. Yogyakarta: Jalasutra.

Damuri, Rizal, Y., Christian, D., \& Antje, R. (2015). Kawasan Ekonomi Khusus dan Strategis di Indonesia. Yogyakarta: PT Kanisius.

Eriyanto. (2001). Analisis Wacana: Pengantar Analisis Teks Media. Yogyakarta: LKiS.

Fairclough, N. (1989). Language and Power. London: Longman.

Fairclough, N. (1995). Critical Discourse Analysis. London: Longman.

Hall, S. (1997). Representation: Cultural Representations and Signifying Practices. London: Sage in association with Open University.

Kovach, B., \& Rosenstiel, T. (2003). Sembilan Elemen Jurnalisme. Jakarta: PANTAU.

Margianto, J., \& Syaefullah, A. (2004). Media Online: Pembaca, Laba dan Etika. Jakarta: Aliansi Jurnalis Independen Indonesia.

Peress, J. (2014). The media and the diffusion of information in financial markets: Evidence from newspaper strikes. The Journal of Finance, 69(5). doi:10.1111/jofi.12179 
Puette, W. J. (1992). Through Jaundiced Eyes: How the Media View Organized Labor. Ithaca, NY: Cornell University.

Ricoeur, P. (2012). Teori Interpretasi: Memahami Teks, Penafsiran dan Metodologinya. (M. Hery, Trans.) Jogjakarta: IERCiSoD.

Robertson, G. B. (2007, November). Strikes and Labor Organization in Hybrid Regimes. American Political Science Review, 101(4). doi: 10.1017/S0003055407070475

Schmidt, D. E. (1993, June). Public opinion and media coverage of labor unions. Journal of Labor Research, 14(2), 151-164.

Sheyholislami, J. (n.d.). Critical Discourse Analysis. Retrieved from Carleton University: http://httpserver.carleton.ca/ jsheyhol/articles/what\%20is\%20CDA.pdf

Shoemaker, P. J., \& Reese, S. D. (1996). Mediating the Message. New York: Longman Publisher.

Silvey, R. (2003). Spaces of protest: gendered migration, social networks, and labor activism in West Java, Indonesia. Political Geography, 22, 129-155.

Simon, A., \& Xenos, M. (2000). Media Framing and Effective Public Deliberation. Political Communication, 363-376.

snw. (2015, August 16). Wow Ekonomi Lesu Investasi di Batam Justru Naik 300 Persen. Retrieved August 28, 2015, from batamnews.co,id: http://batamnews.co.id/berita-5990-wow-ekonomi-lesu-investasi-di-batamjustru-naik-300-persen.html

Stefanus, J. (2015, July 11). keprinet.com. Retrieved September 2, 2015, from keprinet.com: http://keprinet.com/2015/07/11/kepri/uba-investasi-asing-kebatam-melalui-singapura/

Website Pemerintah Kota Batam. (2015, September 2). Retrieved September 2, 2015, from batamkota.go.id: http://mediacenter.batamkota.go.id/sulit-diprediksibanyak-perusahaan-keluhkan-kenaikan-upah/ 